\title{
Seismic Retrofitting of Irregular Pre-80s Low-rise Conventional RC Building Structures
}

\author{
Han, A.L. ${ }^{1}$, Utomo, J.2*, Hu, H.T. ${ }^{3}$, and Lestari, L.T. ${ }^{1}$
}

\begin{abstract}
A resilience and seismic safety evaluation method of under-qualified concrete structures designed based on codes prior to the introduction of earthquake provisions is presented. A numerical method for evaluating and improving a structure's performance and resilience through jacketing and Carbon Fiber Reinforced Polymers (CFRP) retrofitting was developed. The model analyzed the structure's existing condition, inadequate elements were identified, and segments that required strengthening were determined. Retrofitting and external reinforcing techniques were applied, and their effectiveness evaluated. Elements identified as insufficient were subjected to a strengthening iteration process to ensure that all qualifications were fulfilled. It was proven that the numerical simulation was accurate, cost-effective and time-saving in evaluating deficient structures and the effectiveness of their strengthening methods. The numerical model and analysis in conjunction with the technology of jacketing and CFRP retrofitting provide a fast and straightforward solution for older structures in ameliorating their resilience and overall performance.
\end{abstract}

Keywords: Earthquake-resilience; retrofitting techniques; jacketing; Carbon Fiber Reinforced Polymers (CFRP).

\section{Introduction}

The well-known capacity design principle is the control of a structure's inelastic responses through an engineered strength hierarchy. This concept was introduced in the 1980s. Buildings designed prior to the ' 80 s were not detailed to perform adequately under severe earthquakes. This condition was exacerbated by the presence of significant irregularities. The presence of asymmetrical infilled masonry walls or staircases located at corners of the building causes eccentricity in mass and stiffness distributions, leading to the possibility of significant damage to specific parts of the building [1]. A large existing stock of reinforced concrete buildings dated prior to 1980 can be categorized as substandard and seismically deficient $[2,3]$. These buildings require a comprehensive assessment of their seismic response. Seismic retrofitting is a cost-effective method for improving the earthquake resilience of these structures.

\footnotetext{
1 Department of Civil Engineering, Faculty of Engineering, Universitas Diponegoro, Prof. Soedarto, SH. Road, Tembalang, Semarang 50275, INDONESIA

${ }^{2}$ Department of Civil Engineering, Faculty of Engineering, Universitas Atma Jaya Yogyakarta, Babarsari Road, Sleman, Yogyakarta 55281, INDONESIA

${ }^{3}$ Department of Civil Engineering, National Cheng Kung University, Dasyue Road, East District, Tainan City 701, TAIWAN

*Corresponding author; Email: jun.utomo@gmail.com.
}

Note: Discussion is expected before July, $1^{\text {st }} 2021$, and will be published in the "Civil Engineering Dimension", volume 23, number 2, September 2021.

Received 31 December 2020; revised 01 January 2021; accepted 23 January 2021
Retrofitting strategies, methods of analysis and special-purpose software for seismic assessment and strengthening are available to speed up the retrofitting design of existing buildings [3,4]. A non-linear pushover analysis is used to investigate the weak components and deficiencies of buildings under various target structural performance levels $[5,6]$. The functionality of buildings is improved simultaneously by increasing the stiffness, strength, and deformation capacity of the structure. The expected impact of the retrofitting strategies is evaluated based on a sensitivity analysis of the vulnerability of various components of the buildings $[7,8]$.

This paper deals with the construction of a numerical model that can represent any existing concrete structure. The model was executed using non-linear material and geometric software; a typical three-story building was used for simulation purposes. The model was designed to identify the elements within the structure that are inadequate and therefore require enhancement through retrofitting. Considering the advantages of Carbon Fiber Reinforced Polymers (CFRP), this material was superimposed into the model to enhance, through external reinforcement, the performance of the member and the overall structure. At the next stage, the model is used to reevaluate the effectiveness of the retrofitting, and to evaluate the stress levels within the elements under consideration. The outcome presented a fast and satisfactory method to revitalize older buildings to meet the higher code demands. 


\section{Materials and Method}

\section{Non-Linear Method and Knowledge of Struc- tural Detailing}

Four different methods are proposed by the majority of codes and standards for determining the forces and corresponding deformations of the members in a structure due to the ground motion interrelated with the designed seismic hazard level. These procedures are as follows:

- The Linear Static Procedure (LSP) is known in practice as equivalent static analysis. The effects of earthquakes are represented by static forces applied at floor levels. The static forces are calculated using the first mode of vibration. Because of the simplifying assumption, the LSP can only represent the dynamic behavior of regular structures.

- The Linear Dynamic Procedure (LDP) is known as response spectrum analysis. The earthquake response spectrum is used to predict displacements and internal forces in structures. The designer has the freedom to include only those modes of vibration that make a significant contribution to the dynamic response of a structure.

- The Non-linear Static Procedure (NSP) is pushover analysis. Constant gravity loads and monotonically increased lateral forces are used to construct the capacity curve of the structures. The capacity curve obtained from a pushover analysis represents the strength and deformation capacities of the structure. The capacities of the structures are then compared with the demands at each performance point of interest.

- The Non-linear Dynamic Procedure (NDP) was developed to capture the dynamic response of the structures without simplifying assumptions. The non-linear load-deformation properties of each element are incorporated in the NDP. Earthquake accelerograms are used in the dynamic analysis to determine the design displacements of the structures directly.

The resilience of buildings can be improved by increasing the structure's strength, stiffness, and deformation capacity. The codes and the availability of knowledge of the buildings function as a guide to the linear and non-linear methods employed. Linear methods are not considered to be accurate and codes do not recommend their use for buildings with structural irregularity. However, it might be permitted in cases where in-depth knowledge of the structural configuration is not available. Both the lack of good knowledge of a building's status and the lack of accuracy in the analysis are compensated by safety factors.
On the other hand, it is not permitted to employ advanced non-linear methods when the knowledge of the structure is poor. The linear methods, LSD and LDP, result in a less accurate outcome since the behavior of a concrete structure is highly non-linear. The NSP and NDP methods yield more realistic results, but an in-depth knowledge of the structure, including all elements' configurations and details, is mandatory. The SeismoBuild [9] software is based on the NSP method, and both the NSP and NDP methods are supported by Seismo Struct [10], used in this research work.

The software used in this paper, SeismoStruct, employs advanced non-linear dynamic analysis, and earthquake accelerograms are used in the dynamic analysis, yielding thorough outcomes. However, a pushover analysis option is available in SeismoStruct to ascertain the capacity curve of the structure used in this paper. Additionally, the pushover analysis imparts information on a range of response characteristics that are not available when using the linear methods. It can be concluded that the pushover analysis is the most suitable approach for performing seismic assessment and analyzing the design for retrofitting.

The retrofitted building analyzed in this work was modeled using computer software (Seismo Struct), while the seismic resistance was approached using the non-linear pushover method. Performance-based approaches developed by the Structural Engineers Association of California (SEAOC) Vision 2000 Committee [11] will be employed in this work for the assessment and retrofitting of the building.

The performance-based design utilizes a performance objective to conclude a satisfactory damage level for new as well as for revitalized, existing structures. These performance objectives of the structure and the non-structural elements can limit story drift and minimize component damage in order to fulfill the targeted performance level. The first step in performance-based design is to establish the performance objectives, described as the combination of a performance level with expected levels of hazard (e.g. ground motion, and extreme wind). A performance level is a standard for the maximum damage level permitted on a building. Performance objectives, which are expressed as discrete points, such as limited damage, significant damage or near-collapse subsequent to a designed earthquake, are the benchmark in characterizing the state of the building. The outline of the method, including retrofitting design, evaluation and probable re-design for the retrofitting plan, is presented in Figure 1 [12]. 


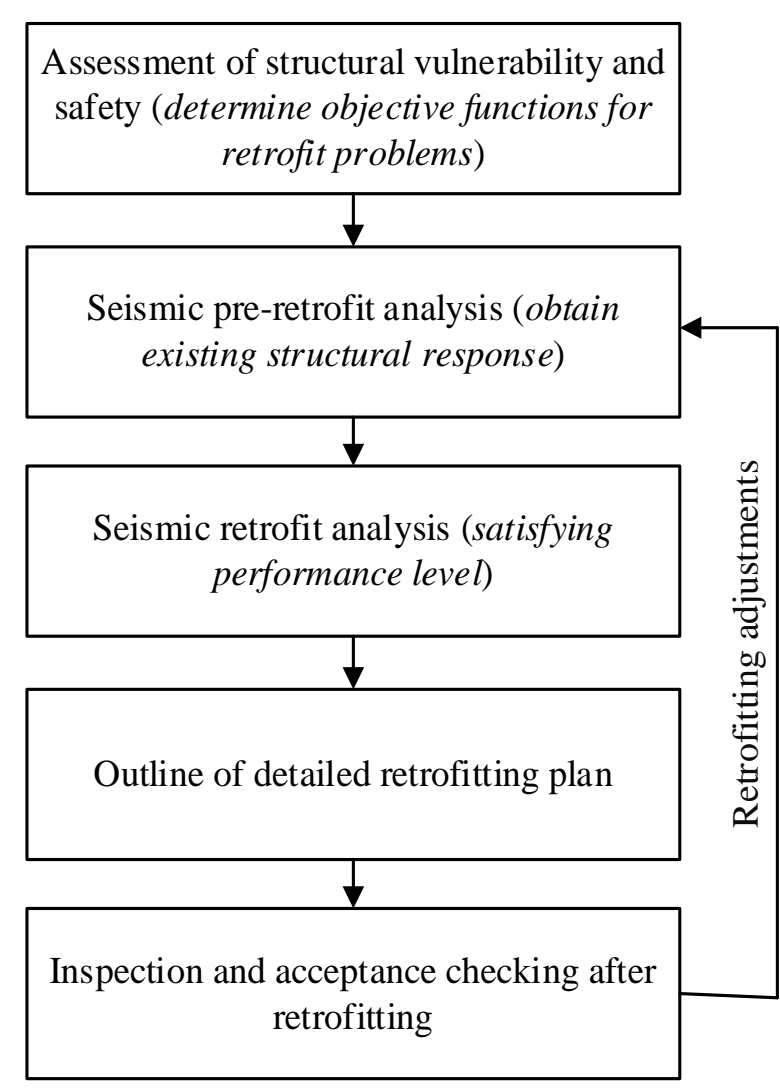

Figure 1. Outline of Analysis and Retrofitting Method

\section{Retrofitting Strategies and Intervention}

Retrofitting is a method for improving the resistance and resilience of a building under the response of earthquake loads by optimizing the composite action between the old concrete and the retrofitting material and methods. Interventions are generally applied to specific parts of the building (e.g. a weak story). Retrofitting of small parts in a building is very efficient and economical while also minimizing the interference on the building. The strategy includes the collection of data on the reinforcement details of the as-built structure and material properties [13].

Retrofitting becomes mandatory when the assessment of structures results in an insufficient capacity to resist the forces of an expected intensity within the acceptable damage limits. The retrofitting goals include the following strategies:

- The first strategy is seismic demand reduction of the members and the building's structure as a unity. Adding concrete walls is an example of this strategy. Concrete walls can reduce the seismic demands throughout the building and are efficient in controlling global lateral drifts and damage to both structural and non-structural components [4]. To ensure the integrity of the system, new walls should be utilized with appropriately designed foundations. Another illustration of this strategy is the installation of dampers situated at a strategic location in the structures [14]. Dampers that can reduce the seismic demands on structures include friction, metallic or viscous dampers. Low-cost dampers, such as metallic dampers manufactured from steel pipes, are highly cost-effective in reducing seismic demand [15]. The use of base isolators is another alternative illustration of this strategy $[15,16]$.

- The second approach is to enhance the loadcarrying capacity of the individual members. Examples include strengthening beams and columns using steel jackets, concrete jackets, or CFRP wrappings [17-19]. The employment of concrete haunches at the beam-to-column connections is also a method associated with this approach [20,21].

An effective way to overcome a low lateral force resistance and deficiencies of structures is to incorporate the two abovementioned strategies into one system. This method involves a combination of the addition of new members and the strengthening of existing members. Each building is specific and different approaches depending on the structural deficiencies are required. The results of the chosen retrofit techniques must fulfill the minimum requirements outlined in the building codes, such as element deformation capacity, strength, and detailing. The fact that the majority of existing buildings are inhabited creates a challenge for engineers in designing these interventions, and the proposed methods should accommodate their daily activities. The use of non-linear methods and a good knowledge of the condition of the building can be greatly advantageous, leading to significantly lighter interventions [13].

\section{Common Strengthening Techniques for Retrofitting Buildings}

The techniques for strengthening members are distinguished according to the primary material. Jacketing is a strengthening process where a part or a section of an existing structural concrete member is increased in size by capsuling or encasing using steel, concrete, or another suitable material, such as fiber. Three common strengthening techniques are:

- Steel jacketing. In steel jacketing, the reinforced concrete section is enlarged using L-shaped steel sections situated with a gap of 2 to $3 \mathrm{~mm}$ to the concrete surface. This gap is filled with a grouting component. These $\mathrm{L}$ sections are connected with steel strips welded to the L profiles. This method is effective in enhancing the seismic performance of the elements but is costly, labor-intensive and involves anti-rust work. Due to the alterations in the section, this method also influences the stiffness of the elements. 
- CFRP jacketing. CFRP jacketing is one of the preferred options in terms of seismic retrofitting methods, which is primarily due to the many advantages of the CFRP composites compared with steel and concrete jacketing, such as ease and speed of installation, less labor required, minimal change to the cross-section, high strength-toweight ratio, and minimal impact on the usability of the building. However, it has disadvantages, such as premature debonding [18,19,22], high cost, and is sensitive to high temperatures or wet environments. CFRP is generally bonded externally to reinforced concrete columns using epoxy resins. Complete wrapping is used for strengthening columns subjected to uniaxial or biaxial bending [23]. Reinforced concrete columns retrofitted with external CFRP jacketing exhibit a stable flexural response, improved ductility and energy dissipation capacity by preventing brittle shear failure. Due to geometrical restrictions, complete wrapping may not always be possible for beams, in which case either three-sided U wrapping or two-sided bonding on the two opposite faces of the beams can be applied.

- Concrete jacketing. Concrete jacketing is still the method of choice for seismic retrofitting of individual concrete members, because it does not require highly sophisticated workmanship. However, it is labor-intensive and time-consuming due to the installation of formwork. A layer of reinforced concrete is cast, covering the outer perimeters of an existing member. The concrete jacket is very suitable for severely damaged members, and encapsulates members and joints, while providing structural continuity between the joint and adjoining members. The stiffness, strength, and deformation capacity of the existing members can be improved simultaneously. The thickness of the jacket is around $100 \mathrm{~mm}$ and can be reduced to $50 \mathrm{~mm}$, allowing for the concrete casting. A thin jacket is produced using shotcrete or self-compacting concrete. If reinforced concrete jacketing is selected, it typically requires the strengthening of all or almost all the columns of the building, at least on the lower floors, to maintain the stiffness of these elements [13]. Alternatively, the strengthening can be designated for outdoor elements only, so that the usability of the structure is unaffected.

Localized strengthening of beam-column joints using a joint panel is designed to avoid joint shear failure. Advanced studies are needed to quantify the benefits of this local strengthening technique for the overall seismic response [24]. A concrete jacket increases the moment resistance and stiffness of a column and can be extended to the joint, beyond the end of the column, providing continuity between the column and the joint and, at the same time, strengthening the joint itself [13]. A state-of-the-art review of different strengthening and repair techniques for reinforced concrete columns over the last two decades has been conducted [25]. Based on the review, it is believed that hybrid jacketing techniques, which combine the benefits of different materials/strengthening methods, such as near-surface mounted CFRP bars and CFRP wrapping, and concrete jacketing can be the most effective strengthening methods.

\section{Retrofitting Asymmetric Reinforced Concrete Frame Buildings: A Worst-case Scenario}

Reinforced concrete frames with masonry infilled panels are very popular in tropical areas. The brick masonry is easily available and simple in construction. Masonry panels are cheap and provide good weather protection [2,26]. Masonry infilled panels act as separators among rooms with different functionalities, provide additional stiffness to the RC frames and significantly increase the natural frequency of the building [27]. As the natural frequency increases, the lateral displacement decreases. The presence of masonry infilled panels creates diagonal struts, which might not have been anticipated in the original design of the buildings. If the masonry panels are not attached properly to peripheral frame members, the panels could fail due to face loads (inertial forces due to an earthquake perpendicular to the panel) generated by strong earthquakes. The face loads also cause panels to be vulnerable to cyclic, outof-plane deformation. The mechanisms of the seismic response of confined masonry buildings for in- and out-of-plane seismic effects were explained thoroughly in the Seismic Design Guide for Low-Rise Confined Masonry Buildings [28]. Some retrofitting interventions might be required to strengthen masonry panels $[29,30]$. If not properly retrofitted, the repair costs for masonry infilled panels that do not have an adequate seismic strength can be significant [31]. There are three main failure mechanisms for infill panels: compression, shear, and diagonal tension. The Crisafulli model [32] is extensively used for masonry infilled panels and implemented in the SeismoStruct software used in this simulation. The $\mathrm{RC}$ beams in the buildings were assumed to be noncorroded beams, so there was no need to replace the cracked concrete substrate with high-strength polymer-modified cementitious mortar before strengthening [33].

\section{Analyses and Discussion}

Infilled panels alter the stiffness, strength, and ductility of a structure. Irregularities and a low lateral force resistance are normally present in substandard buildings designed and constructed prior to the 
implementation of seismic design provisions. The seismic assessment of a building with a nonengineered three-story irregular reinforced concrete frame and masonry infilled panels was carried out as a worst-case scenario. The results of the assessment were used to determine whether the building required retrofitting. The building represents a substandard reinforced concrete building built in the late '80s. The plan view of the building is shown in Figure 2a and the 3-D view of the deformed shape of the building, with masonry infilled panels at the corners of the second and third stories, is shown in Figure 2b.

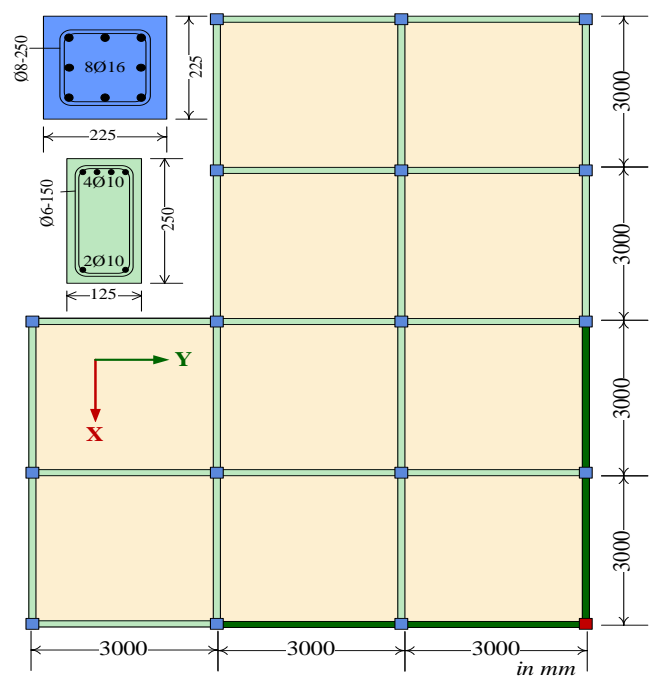

(a)

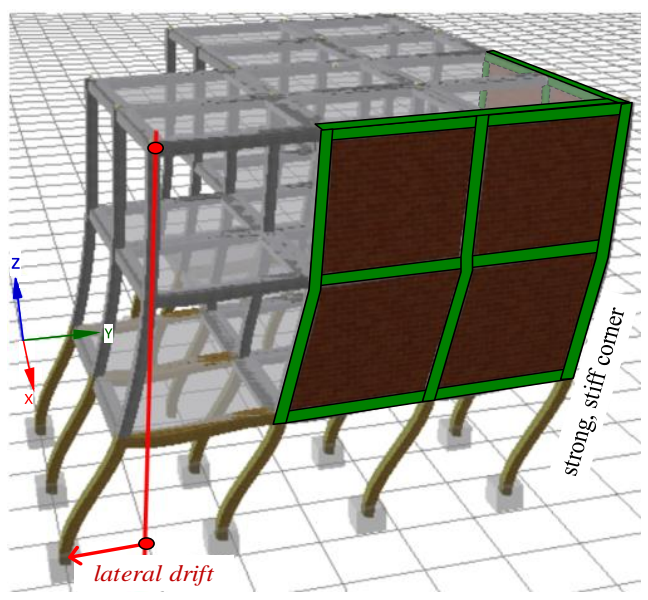

(b)

Figure 2. The Building Plan and 3-D Model of the Investigated Building Before Retrofitting: (a) The First-floor Plan of the Building; (b) 3-D Deformed Shape of the Building

The building plan consisted of 3 bays in the $\mathrm{Y}$ direction and 4 bays in the $\mathrm{X}$ direction. The span in each direction, as well as the floor height, was 3.0 meters. The slab thickness of the building was 150 $\mathrm{mm}$, while the details of the beam and column crosssections are shown in Figure 2a. A superimposed dead load of $1.5 \mathrm{kPa}$ and a live load of $2.0 \mathrm{kPa}$ were applied in addition to the self-weight of the structure. The peak ground acceleration (PGA) for the earthquake design was taken to be $0.240 \mathrm{~g}$. The concrete compression strength $\left(f_{c}^{\prime}\right)$ was $16 \mathrm{MPa}$. This low strength is characteristic of older buildings when material technology was less advanced. The steel has a yield stress $\left(f_{y}\right)$ of $244 \mathrm{MPa}$, which also represents the materials commonly used in the late '80s.

The use of masonry infilled panels created a weak story, leading to failure at the soft first-story levels. The infilled panels are positioned near one of the corners to simulate the large lateral stiffness induced by a staircase $[1,34]$. The response of the building is defined by floor torsion at the stiff and strong corner of the building (Figure 3). Columns at the flexible side of the building develop large deformation demands that are not fulfilled by the capacity of the columns. During the simulation, the demand-capacity ratio, also known as the performance ratio, of these columns is larger than 1.0.

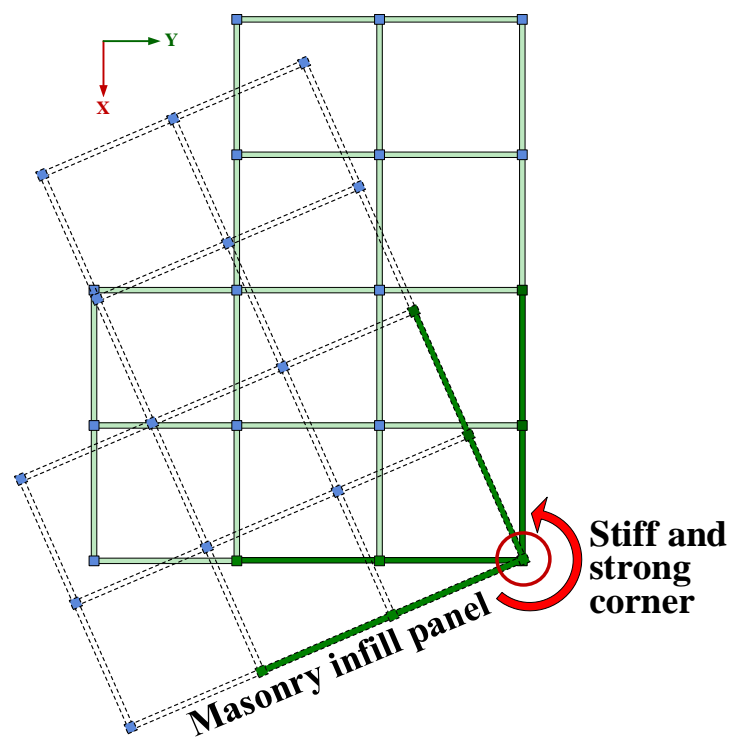

Figure 3. Stiff and Strong Corner of a Building and the Rotational Deformation

A seismic assessment was conducted using the Seismo Build and Seismo Struct software. This software is able to carry out code definition checks. The Eurocode 8, Part 3 option was activated in Seismo Build for the seismic assessment. The axes of the building are shown in Figure 3. The building was more flexible in the $\mathrm{Y}$ direction; therefore, the eight user-defined load combinations, with a uniform load pattern, shown in Figure 4, were used in the nonlinear pushover analysis. $0.3 X$ represents $30 \%$ of the earthquake load in the $\mathrm{X}$ direction, $\mathrm{Y}$ is $100 \%$ of the earthquake load in the $\mathrm{Y}$ direction, and $e c c X$ is the effect of $5 \%$ default accidental eccentricity in the $\mathrm{X}$ direction. The negative sign stands for the load working in the opposite direction. 


\begin{tabular}{|c|c|c|c|c|c|}
\hline \multicolumn{2}{|c|}{ Predefined Pattern Schemes } & No. & Type & \multirow{2}{*}{$\begin{array}{l}\text { Load Pattern } \\
\text { Uniform }\end{array}$} & \multirow{2}{*}{$\begin{array}{l}\text { Combination } \\
+0.3 X+Y+e c c X\end{array}$} \\
\hline & $\checkmark$ & $\square$ No.49 & Biaxial with $X$ Eccentricity & & \\
\hline & & $\nabla_{N o .50}$ & Biaxial with $\times$ Eccentricity & Uniform & $+0.3 X+Y-\operatorname{ecc} X$ \\
\hline \multicolumn{2}{|l|}{ Pattern } & $\nabla$ No.51 & Biaxial with $\times$ Eccentricity & Uniform & $+0.3 X-Y+e c c X$ \\
\hline \multicolumn{2}{|l|}{$\square$ Uniform } & $\square_{\text {No. }} 52$ & Biaxial with $X$ Eccentricity & Uniform & $+0.3 X-Y-\operatorname{ecc} X$ \\
\hline \multicolumn{2}{|l|}{$\square$ Modal } & VNo.53 & Biaxial with $X$ Eccentricity & Uniform & $-0.3 X+Y+e c c X$ \\
\hline \multicolumn{2}{|l|}{ Uniaxial/Biaxial } & $\nabla$ No.54 & Biaxial with $X$ Eccentricity & Uniform & $-0.3 X+Y-\operatorname{ecc} X$ \\
\hline \multicolumn{2}{|l|}{$\square$ Uniaxial } & VNo.55 & Biaxial with $X$ Eccentricity & Uniform & $-0.3 X-Y+e c c X$ \\
\hline \multicolumn{2}{|c|}{$\square$ Biaxial } & $\checkmark$ No.56 & Biaxial with $X$ Eccentricity & Uniform & $-0.3 X-Y-\operatorname{ecc} X$ \\
\hline \multirow{4}{*}{\multicolumn{2}{|c|}{$\begin{array}{l}\text { Accidental Eccenticity } \\
\square \text { Without Eccenticity } \\
\square \text { Single Eccenticity (eccX/eccY) } \\
\square \text { Double Eccenticity (eccX+eccY) }\end{array}$}} & $\square$ No.57 & Biaxial with $X$ Eccentricity & Modal & $+X+0.3 Y+e c c X$ \\
\hline & & $\square$ No.58 & Biaxial with X Eccentricity & Modal & $+X+0.3 Y-\operatorname{ecc} X$ \\
\hline & & $\square$ No.59 & Biaxial with $X$ Eccentricity & Modal & $+X-0.3 Y+e c c X$ \\
\hline & & $\square$ No.60 & Biaxial with $X$ Eccentricity & Modal & $+X-0.3 Y-e c c X$ \\
\hline Select All & Deselect All & $\square$ No.61 & Biaxial with X Eccentricity & Modal & $-X+0.3 Y+e c c X$ \\
\hline \multirow{2}{*}{\multicolumn{2}{|c|}{ No. of Pushover Analyses: 8}} & $\square$ No.62 & Biaxial with X Eccentricity & Modal & $-X+0.3 Y-e c c X$ \\
\hline & & $\square$ No.63 & Biaxial with X Eccentricity & Modal & $-X-0.3 Y+e c c X$ \\
\hline
\end{tabular}

Figure 4. Eight User-defined Load Combinations (no. 49 to no. 56)

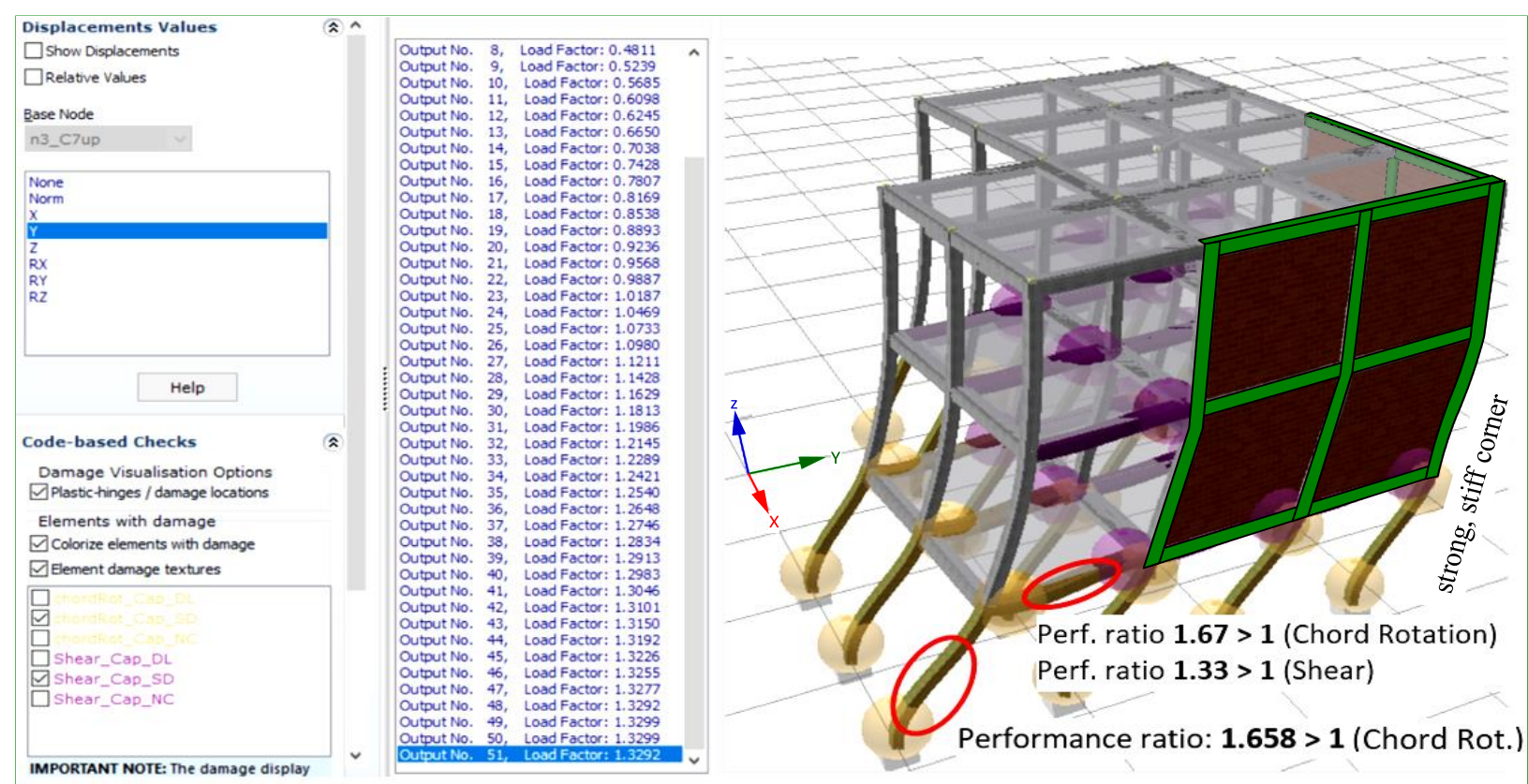

Figure 5. SD Level Pushover Analysis Prior to Retrofitting at $(0.3 X+Y+e c c X)$ Load Combination

Seismo Build does not have facilities to insert masonry infill panels. Seismo Build was used to define the load combinations and the model of all members except for the infill panels. The resulting project was exported to Seismo Struct, where the masonry infill panels were defined, prior to the seismic assessment. The results of the seismic assessment showed a serious structural problem: the lateral deformations and damage were concentrated in the first story, as shown in Figure 2b. Therefore, retrofitting was required to overcome the vulnerability of the existing building.

The retrofitting options considered were: firstly, adding concrete walls to control the global lateral drifts and reduce damage to the frame and nonstructural elements; and secondly, increasing the capacity of the beams and columns. This option represents the second strategy discussed previously. The second strategy was chosen to retrofit the existing building.

The analyses showed that the columns and beams of the existing building required strengthening due to the inadequate shear strength capacity of the members. The first retrofitting option of adding concrete walls from the bottom to the top of the building to absorb a significant amount of base shear at the ground level of the building could eliminate the need for intervention in other structural elements, provided that they have adequate strength and reinforcement. The second retrofitting option, the preferred option, potentially caused a serious disruption of the building's use but had the advantage 
of not notably altering the architecture and aesthetics of the building. This method was exclusively elaborated in this study. The code-based checks in the last step of the pushover analysis for the $(0.3 X+Y+$ ecc $X)$ load combination at the Significant Damage (SD) level indicated a failure of all first-story columns and of all beams on the first and second floors, as shown in Figure 5. Retrofitting was mandatory to eliminate these seismic deficiencies.

To enhance the strength and load-carrying capacity of the first-story columns, the concrete jacketing method was favored. The concrete had a compression strength $\left(f_{c}^{\prime}\right)$ of $27.5 \mathrm{MPa}$ and a steel yield stress of $\left(f_{y}\right)$ of 413
MPa. Jacketed columns with a thickness of $62.5 \mathrm{~mm}$ and additional longitudinal reinforcements, as shown in Figure 6, were used. For beam shear strengthening, the CFRP sheet could not be applied effectively because of the shallow web of the existing beams.

The beam-column capacity was checked by the Seismostruct software. No critical joints were detected. The deformation, chord rotation, and shear capacity requirements demanded that each member of the building be checked against their capacities. More concrete jacketing of the remaining columns and beams was conducted to satisfy all code-based checks for all beams and columns. It was proven that

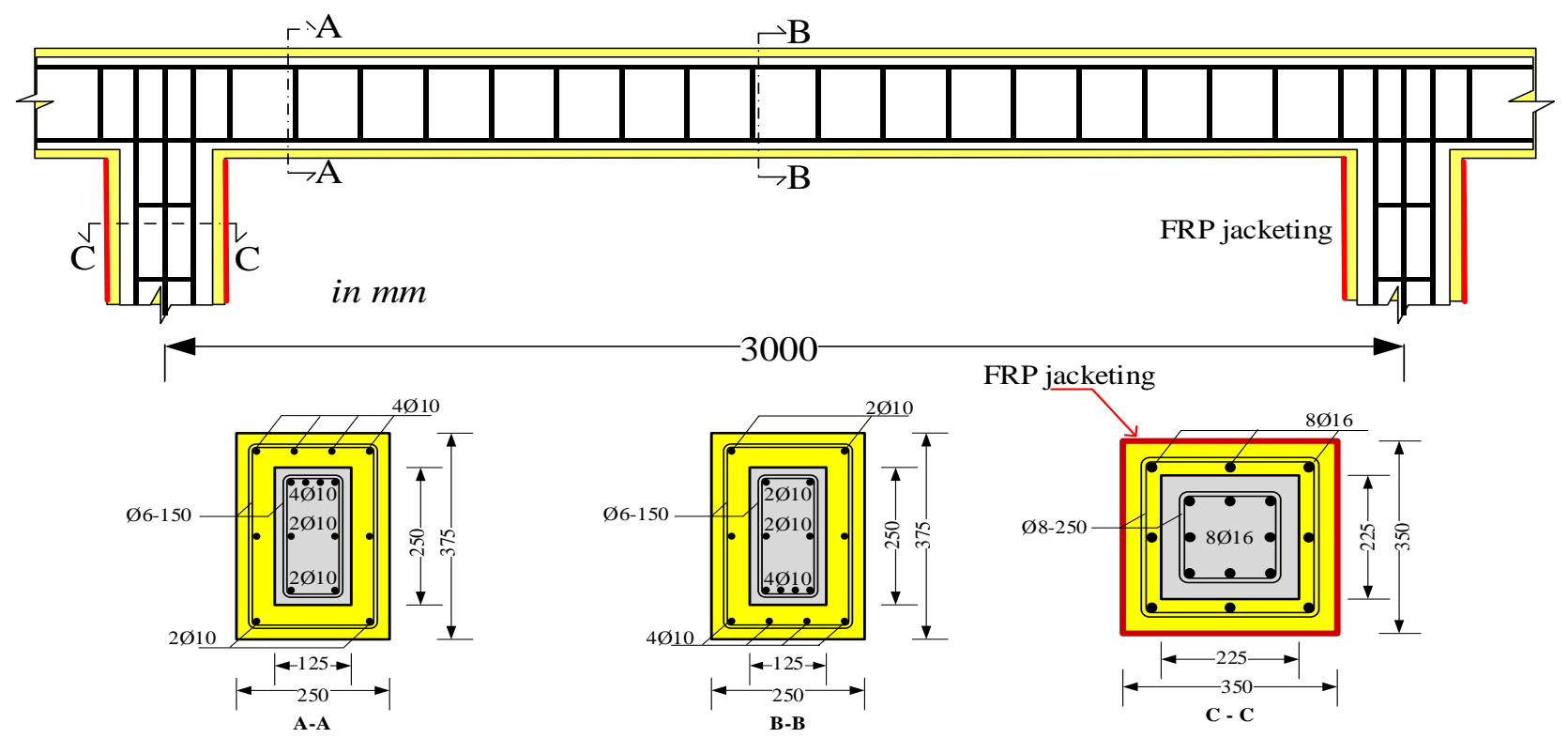

Figure 6. Schematic Representation of the Retrofitting Solution

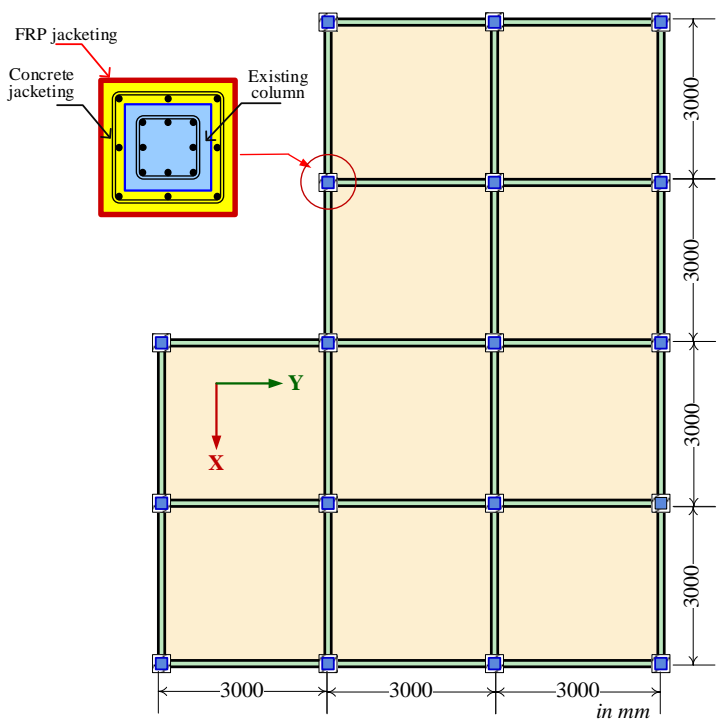

(a)

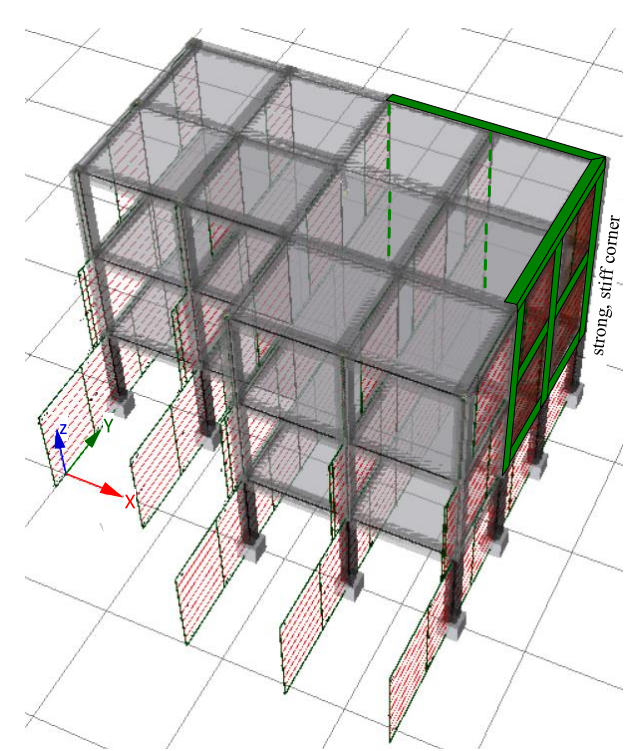

(b)

Figure 7. The First-floor plan and a 3-D Model of the Building after Retrofitting: (a) Strengthened Beams and Columns; (b) Large Shear Demand on the Bottom Story due to the $(0.3 X+Y+e c c X)$ Load Combination 
all jacketed columns and beams satisfied the lateral deformation, chord rotation, and shear capacity requirements, except for the first-story columns, where the demand for chord rotation exceeded the capacities of the columns. To increase the strength of these columns, CFRP wrapping of all jacketed columns was considered. The results of the seismic assessment shown in Figure $7 \mathrm{~b}$ indicate large shear demands on all columns on the first story. The moments to balance these large shear forces at the first story pose large chord rotational demands at the ends of the columns, which were not met by the jacketed columns' capacity (see Figure 7b). To overcome this problem, additional CFRP wrappings on the first-story columns were applied to increase the capacities of these columns. Figure 7 shows the final retrofitted building plan of the first floor and a 3-D view of the building. The retrofitted building has lateral deformations distributed well along the building height. No damage to the first-story columns and fewer failures in the other structural members were detected. Figure 8 shows the results of the last step of the pushover analysis of the existing building at the SD level, after retrofitting for the $(0.3 X+Y+$ $e c c X)$ load combination. The CFRP wrappings significantly increased the capacities of the first-story columns. The performance ratios of the first-story columns are well below the limit of 1 .
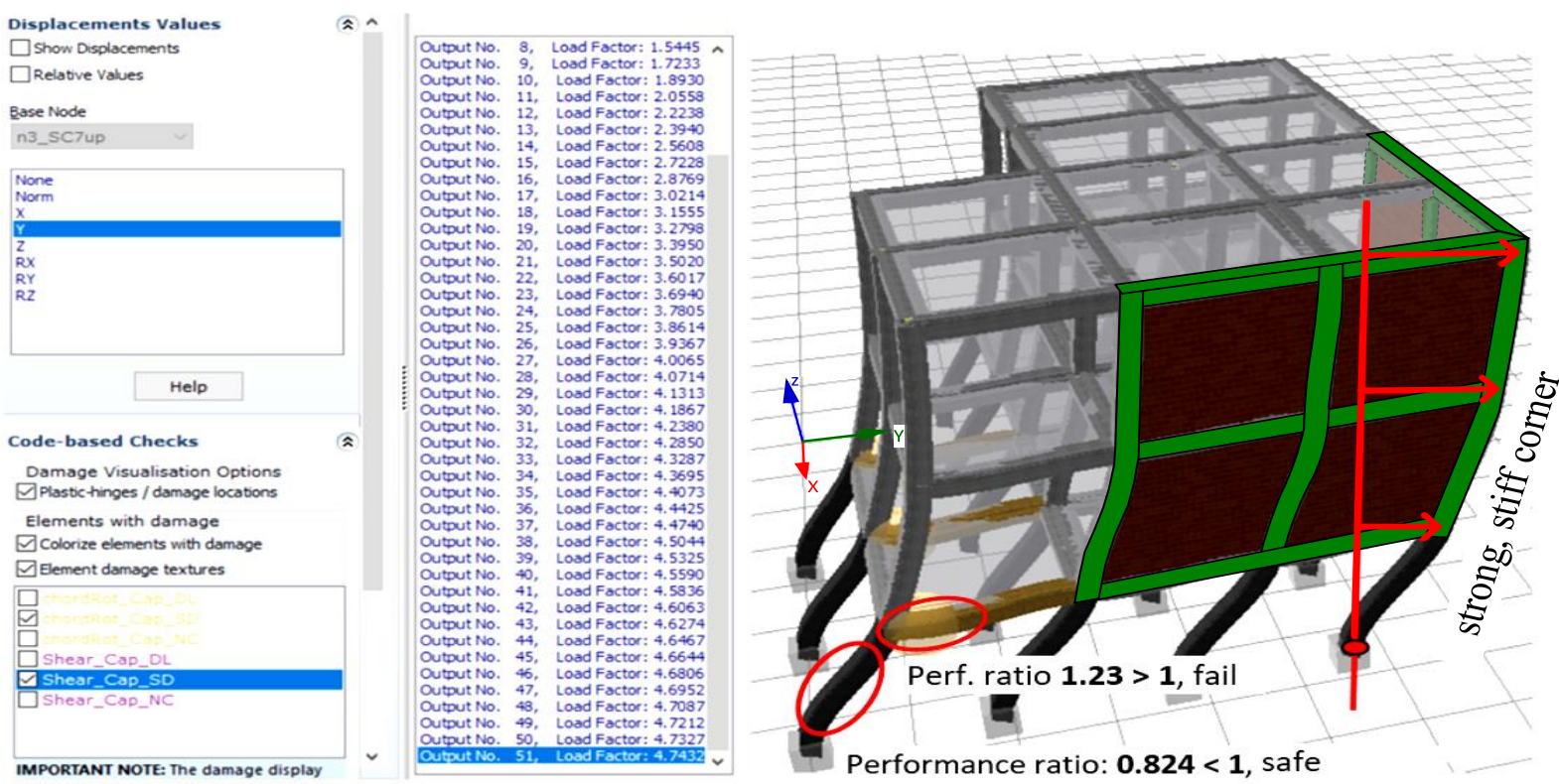

Figure 8. Results of the Last Step of the Pushover Analysis of the Existing Building at the Significant Damage Level, after Retrofitting for the $(0.3 X+Y+e c c X)$ Load Combination

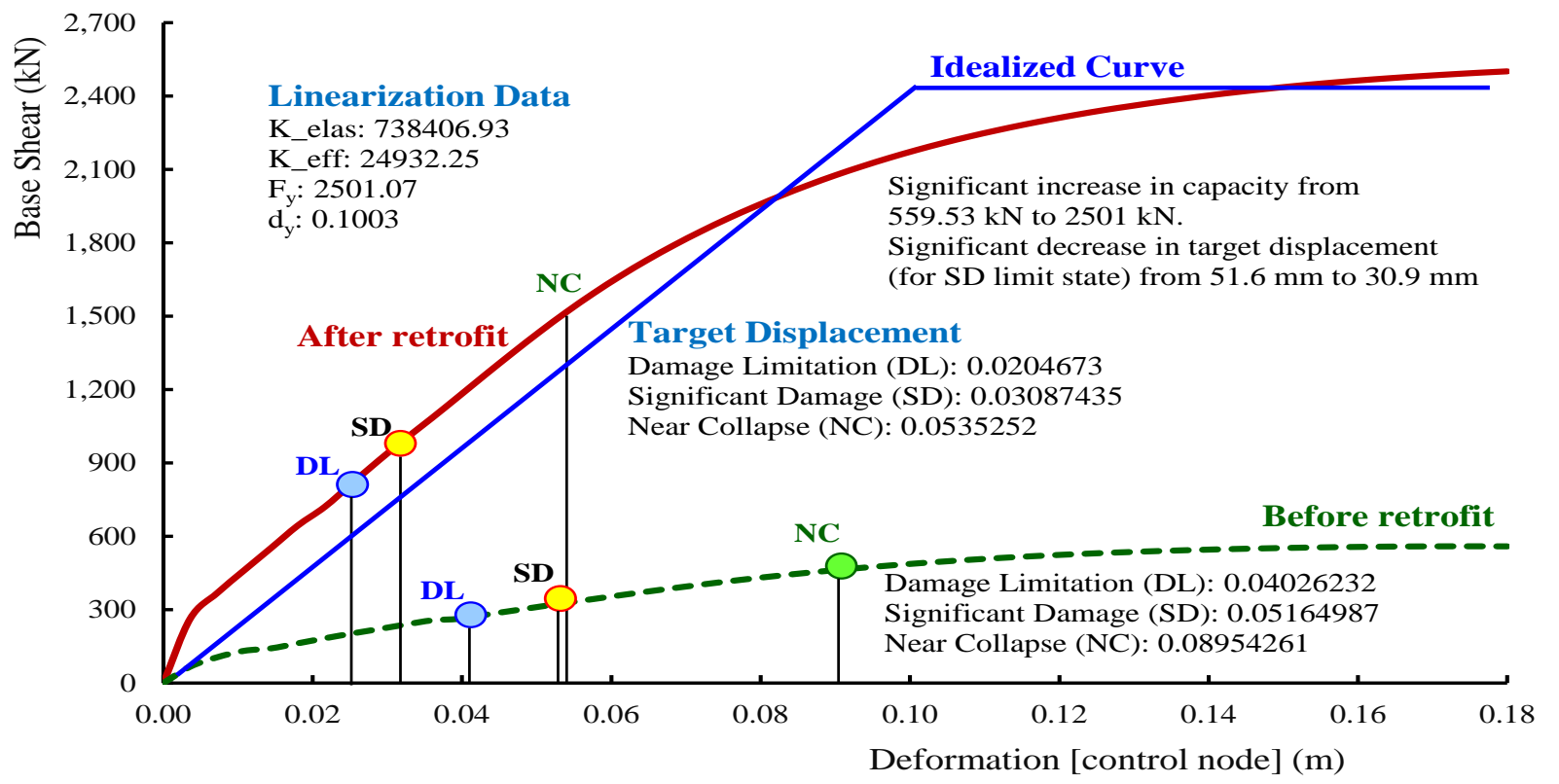

Figure 9. Pushover Curves of the Investigated Building for the $(0.3 X+Y+e c c X)$ Load Combination 
The results of the pushover analyses for the $(0.3 X+Y$ $+e c c X)$ load combination using the Significant Damage (SD) limit state for the retrofitted building resulted in a target displacement of $30.9 \mathrm{~mm}$ in combination with a maximum building load-carrying capacity of $2501 \mathrm{kN}$, as shown in Figure 9. Figure 9 shows a significant increase in the maximum building load-carrying capacity of about $2501 \mathrm{kN} / 559.53 \mathrm{kN}=$ 4.47 times the initial load-carrying capacity of only $559.53 \mathrm{kN}$. The targeted displacement considerably decreased from $52 \mathrm{~mm}$ to $31 \mathrm{~mm}$ and was only $31 / 52$ $=0.596$ times the original lateral deformation.

A detailed assessment of the building can indicate the real seismic deficiencies of the building and properly guide decisions relating to retrofitting strategies. The analyses also showed that the highest demandcapacity ratios or performance ratios from the codebased checks of the eight combinations were rated as follows:

The shear capacity at near collapse, along with the performance ratios, for the eight load combinations used in the analyses are shown in Table 1.

Table 1. Shear Capacity at Near Collapse

\begin{tabular}{cccc}
\hline $\begin{array}{c}\text { Case } \\
\text { number }\end{array}$ & $\begin{array}{c}\text { Load } \\
\text { combination }\end{array}$ & $\begin{array}{c}\text { Performance } \\
\text { ratio }\end{array}$ & Remarks \\
\hline 1. & $0.3 X+Y-e c c X$ & 0.654 & $<1, \mathrm{ok}$ \\
2. & $0.3 X-Y+e c c X$ & 0.659 & $<1, \mathrm{ok}$ \\
3. & $0.3 X-Y-e c c X$ & 0.795 & $<1, \mathrm{ok}$ \\
4. & $-0.3 X+Y+e c c X$ & 0.795 & $<1, \mathrm{ok}$ \\
5. & $-0.3 X+Y-e c c X$ & 0.655 & $<1, \mathrm{ok}$ \\
6. & $-0.3 X-Y+e c c X$ & 0.659 & $<1, \mathrm{ok}$ \\
7. & $-0.3 X-Y-e c c X$ & 0.786 & $<1, \mathrm{ok}$ \\
8. & $0.3 X+Y+e c c X$ & 0.796 & $<1, \mathrm{ok}$ \\
\hline
\end{tabular}

The chord rotation capacity at near collapse for the eight load combinations considered is shown in Table 2 .

Table 2. Chord Rotation Capacity at Near Collapse

\begin{tabular}{cccc}
\hline $\begin{array}{c}\text { Case } \\
\text { number }\end{array}$ & $\begin{array}{c}\text { Load } \\
\text { combination }\end{array}$ & $\begin{array}{c}\text { Performance } \\
\text { ratio }\end{array}$ & Remarks \\
\hline 1. & $0.3 X+Y-e c c X$ & 0.922 & $<1, \mathrm{ok}$ \\
2. & $0.3 X-Y+e c c X$ & 0.958 & $<1, \mathrm{ok}$ \\
3. & $0.3 X-Y-e c c X$ & 0.903 & $<1, \mathrm{ok}$ \\
4. & $-0.3 X+Y+e c c X$ & 0.996 & $<1, \mathrm{ok}$ \\
5. & $-0.3 X+Y-e c c X$ & 0.922 & $<1, \mathrm{ok}$ \\
6. & $-0.3 X-Y+e c c X$ & 1.009 & $\sim 1, \mathrm{ok}$ \\
7. & $-0.3 X-Y-e c c X$ & 0.786 & $<1, \mathrm{ok}$ \\
8. & $0.3 X+Y+e c c X$ & 0.796 & $<1, \mathrm{ok}$ \\
\hline
\end{tabular}

From these analyses, the demands were quantified along with the models of the capacity and seismic hazard. All values for the performance ratios in Table 2 were less than one or very close to one. All the chord rotation capacities at near collapse for the eight load combinations passed the code-based checks. Performing these analyses showed the influence of the stiffness, strength, and deformation capacity on the building's seismic performance [35]. After retrofitting, the earthquake resilience of the building improved significantly. The three target displacement points (Damage Limitation, Significant Damage, and Near Collapse) lie in the linear part of the capacity curve of the building after retrofitting (see Figure 9).

By varying the input of the design earthquake, a different level of performance options can be offered to the owner of the building so that the owner can choose the performance objective that fits his/her means and intentions. Some owners might wish to avoid collapse under a predeterminate earthquake, while other owners might prefer the retrofitted building to achieve a higher performance objective. The cost of retrofitting depends on the amount of investment in the lateral stiffness, strength, and deformation capacity of the existing building.

If one intends to expand the scope of the seismic assessment for similar structural systems, the Incremental Dynamic Analysis (IDA) can be used to develop fragility curves for each structure considered [36]. The IDA for a structure can be performed using SeismoStruct to generate performance data under an incrementally increasing seismic intensity of selected earthquake records. The fragility curves show the structural vulnerability at various performance levels. The fragility curves need to be developed for different seismic regions and used as probabilistic tools for estimating the damage of earthquakes using damage levels.

\section{Conclusion}

Changes in codes and regulations frequently result in an inadequate performance behavior of buildings designed and constructed prior to the changes in these codes. A method and numerical model were developed to analyze these structures through an assessment procedure that enables the identification of elements that are performing insufficiently based on the new regulations. A revitalization plan is designed based on the assessment outcome, to enhance the structure's overall behavior according to the new codes. The outcome further functions as a guide for decisions regarding retrofitting to enhance the earthquake resilience of buildings. The revitalization in this work was focused on jacketing and external reinforcement using concrete and CFRP wraps. The CFRP material was intentionally favored due to its low maintenance cost after application, ease in application and its high strength. The basic theoretical approach was to improve the individual elements' strength and stiffness by increasing the crosssection and creating a confinement to the concrete. It was demonstrated that this method and model is a 
practical tool to assess the behavior and performance of pre-80s RC buildings, especially when irregularities in the plan and structural system are present.

The cost of retrofitting depends on the amount of investment in the lateral stiffness, strength, and deformation capacity of the buildings. By varying the input of the earthquake design, a different level of performance options can be offered to the owner of the building so that the owner can choose the performance objective that fits his/her means and intentions. Some owners might wish to avoid collapse under a predetermined earthquake, while other owners might prefer the retrofitted building to achieve a higher performance objective. Broader research on monitoring and evaluating the performance of old RC buildings in certain seismic regions can be conducted by developing fragility curves and using the curves as probabilistic tools to indicate whether the old RC buildings in those regions show higher probabilities of exceeding the Significant Damage or Near Collapse performance levels. In this way, retrofitting strategies for those buildings can be devised.

A simulation of the method was presented using a three-story concrete building having extreme irregularities due to a non-regular floor plan and the presence of strong and stiff columns that induce a rotation on the building mass. The simulation followed the steps as planned in the method, identified the inadequate members and re-evaluated the improved structure. The outcome showed that concrete jacketing in combination with CFRP retrofitting is a practical yet effective manner to enhance the structure's performance.

\section{References}

1. Abdel Raheem, S.E., Ahmed, M.M.M., Ahmed, M.M., and Abdel-shafy, A.G.A., Evaluation of Plan Configuration Irregularity Effects on Seismic Response Demands of L-Shaped MRF Buildings, Bulletin of Earthquake Engineering, 16, 2018, pp. 3845-3869, doi: 10.1007/s10518018-0319-7.

2. Usta, P. and Bozdağ, Ö., A New Approximate Method for Earthquake Behaviour of Worship Buildings, Civil Engineering Journal, 5(12), 2019, pp. 2665-2685, doi: 10.28991/cej-201903091440.

3. Alashker, Y., Elhady, K., and Ismaeil, M., Effect of Earthquake Loads on School Buildings in The Kingdom of Saudi Arabia, Civil Engineering Journal, 5(1), 2019, pp. 142-152, doi: 10.28991/ cej- 2019-03091232.

4. Guo, T., Xu, Z., Song, L., Wang, L., and Zhang, Z., Seismic Resilience Upgrade of RC Frame Building Using Self-Centering Concrete Walls with Distributed Friction Devices, Journal of Structural Engineering, 143(12), 2017, p. 04017160, doi: 10.1061/(asce)st. 1943-541x.0001901.

5. Anwar, G.A. and Dong, Y., Seismic Resilience of Retrofitted RC Buildings, Earthqake Engineering and Engineering Vibration, 19(3), 2020, pp. 561571, doi: 10.1007/s11803-020-0580-z.

6. Rastegarian, S. and Sharifi, A., An Investigation on the Correlation of Inter-Story Drift and Performance Objectives in Conventional RC Frames, Emerging Sciance Journal, 2(3), 2018, pp. 140-147, doi: 10.28991/esj-2018-01137.

7. Anglade, E., Giatreli, A., Blyth, A., Napoli, B.D., Parisse, F., Namourah, Z., Rodrigues, and H., Ferreira, T.M., Seismic Damage Scenarios for the Historic City Center of Leiria, Portugal: Analysis of the Impact of Different Seismic Retrofitting Strategies on Emergency Planning, International Journal Disaster Risk Reduction, 44, 2020, p. 101432, doi: 10.1016/j.ijdrr.2019.101432.

8. Samadian, D., Ghafory-Ashtiany, M., Naderpour, H., and Eghbali, M., Seismic Resilience Evaluation Based on Vulnerability Curves for Existing and Retrofitted Typical RC School Buildings, Soil Dynamics and Earthquake Engineering, 127(May), 2019, p.105844, doi: 10.1016/j.soildyn.2019.105 844 .

9. Seismosoft, SeimoBuild - A Computer Program for Structural Assesment and Strengthening of Reinforced Concrete Framed Structures, 2020, www.seimosoft.com.

10. Seismosoft, SeimoStruct - A Computer Program for Static and Dynamic Nonlinear Analysis of Framed Structures, 2020, www.seimosoft.com.

11. Poland, C., Hill, J., Sharpe, R., and Structural Engineers Association of California, Vision 2000 : Performance Based Seismic Engineering of Buildings / Prepared for California Office of Emergency Services, in Performance Based Seismic Engineering of Buildings, Structural Engineers Association of California, 1995.

12. Bai, J., Jin, S., and Ou, J., An Efficient Method for Optimizing the Seismic Resistance of Reinforced Concrete Frame Structures, Advances in Structural Engineering, 23(4), 2020, pp. 670-686, doi: 10.1177/13694332 19878856.

13. Fardis, M.N., Seismic Design, Assessment and Retrofitting of Concrete Buildings: Based on ENEurocode8, 8. 2009.

14. Sabino, A., Mannella, A., and de Leo, A.M., Seismic Response of a Structure Equipped with an External Viscous Damping System, Buildings, 10(19), 2020, doi: 10.3390/buildings100 20019.

15. Utomo, J., Pengembangan Pendisipasi Energi dari Pipa Baja Untuk Proteksi Seismik Bangunan, Disertation, Institut Teknologi Bandung, 2017. 
16. Mansouri, S. and Nazari, A., The Effects of Using Different Seismic Bearing on the Behavior and Seismic Response of High-Rise Building, Civil Engineering Journal, 3(3), 2017, pp. 160-171, doi: 10.28991/cej-2017-00000082.

17. Rasheed, H.A., Strengthening Design of Reinforced Concrete with FRP. 2014.

18. Tudjono, S., Han, A.L., and Gan, B.S., Revitalization of Cracked Flexural Members Using Retrofitting and Synthetic Wrapping, Procedia Engineering, 171, 2017, pp. 1123-1128, doi: 10.1016/ j.proeng.2017.01.472.

19. Tudjono, S., Han, A.L., and Gan, B.S., An Integrated System for Enhancing Flexural Members' Capacity Via Combinations of the Fiber Reinforced Plastic Use, Retrofitting, and Surface Treatment Techniques, International Journal of Technology, 9(1), 2018, pp. 5-15, doi: 10.14716/ ijtech.v9i1.298.

20. Purwanto, Han, A.L., Ekaputri, J.J., Nuroji, and Prasetya, B.H., Geopolymer Haunch Retrofitting for Moment Resisting Frames, Submitted to: Advanced Concrete Constructurion.

21. Akbar, J., Ahmad, N., and Alam, B., Seismic Strengthening of Deficient Reinforced Concrete Frames Using Reinforced Concrete Haunch, ACI Structural Journal, 116(1), 2018, doi: 10.14359/ 51710874.

22. Suprapto, H., Tudjono, S., and Susilorini, R.M.R., Study of the Role of CFRP Shear on Increased Bending Capacity of Reinforced Concrete Beams, in Engineering, Information and Agricultural Technology in the Global Digital Revolution, 2020, pp. 134-138, https://doi.org/10.1201/97804 29322235-28

23. Manie, S., Jami, E., and Azarian, Z., Simplified Design of FRP-Confined Square RC Columns Under Bi-Axial Bending, Buildings, 7, 2017, doi: 10.3390/buildings7030074.

24. Del Vecchio, C., Di Ludovico, M., Prota, A., and Manfredi, G., Modelling Beam-Column Joints and FRP Strengthening in the Seismic Performance Assessment of RC Existing Frames, Composite Structures, 142, 2016, pp. 107-116, doi: 10.1016/j.compstruct.2016.01.077.

25. Raza, S., Khan, M.K.I., Menegon, S.J., Tsang, H.H., and Wilson, J.L., Strengthening and Repair of Reinforced Concrete Columns by Jacketing: State-of-the-Art Review, Sustainability, 11(11), 2019, doi: 10.3390/su11113208.

26. Manfredi, V. and Masi, A., Seismic Strengthening and Energy Efficiency: Towards an
Integrated Approach for the Rehabilitation of Existing RC Buildings, Buildings, 8(3), 2018, doi: 10.3390/buildings8030036.

27. Roudane, B., Adanur, S., and Altunişik, A.C., Numerical Modeling of Masonry Infilled Reinforced Concrete Building During Construction Stages Using Abaqus Software, Buildings, 9(8), 2019, doi: 10.3390/buildings9080181.

28. Meli, R., Brzev, S., Astroza, M., Boen, T., Crisafulli, F., Dai, J., Farsi, M., Hart, T., Mebarki, A., Moghadam, A.S., Quiun, D., Tomazevic, M., and Yamin, L, Seismic Design Guide for Low-Rise Confined Masonry Buildings, Earthquake Engineering Research Institute, Oakland, California, 2011.

29. Coccia, S., Di Carlo, F., and Imperatore, S., Masonry Walls Retrofitted with Vertical FRP Rebars, Buildings, 10(4), 2020, doi: 10.3390/ BUILDINGS10040072.

30. Furtado, A., Vila-Pouca, N., Varum, H., and Arêde, A., Study of the Seismic Response on the Infill Masonry Walls of a 15-Storey Reinforced Concrete Structure in Nepal, Buildings, 9(2), 2019, doi: 10.3390/buildings9020039.

31. De Risi, M.T., Del Gaudio, C., and Verderame, G.M., Evaluation of Repair Costs for Masonry Infills in RC Buildings from Observed Damage Data: The Case-Study of the 2009 L'Aquila Earthquake, Buildings, 9(5), 2019, doi: 10.3390/ buildings9050122.

32. Crisafulli, F., Seismic Behaviour of Reinforced Concrete Structures with Masonry Infills, Doctoral Dissertation, University of Canterbury, New Zealand, 1997.

33. Triantafyllou, G., Rousakis, T., and Karabinis, A., Corroded RC Beams at Service Load Before and After Patch Repair and Strengthening with NSM CFRP Strips, Buildings, 9, 2019, doi: 10.3390/ buildings9030067.

34. Al Mamun, A., Seismic Damage Assessment of Reinforced Concrete Frame Buildings in Canada, Thesis, University of Ottawa, 2011 University of Ottawa, Thesis, 2011.

35. Joyner, M.D. and Sasani, M., Building Performance for Earthquake Resilience, Engineering Structures, 210, 2020, doi: 10.1016/j.engstruct. 2020.110371.

36. Karakaš, N., Kalman Šipoš, T., and HadzimaNyarko, M., Application of Different Seismic Analyses to RC Structures, Elektron. časopis gradevinskog Fak. Osijek, 17, 2018, pp. 39-51, doi: 10.13167/2018.17.5. 